\title{
The Macroeconomic Factors Impact on Liquidity Risk: The Albanian Banking System Case
}

PhD. Cand. Doris Madhi

University Aleksander Xhuvani, Faculty of Economy

\begin{abstract}
Over the last five years, the Albanian banking system has experienced a deceleration on its activity, considering the recent financial crisis effects. The financial crisis did not propagate direct effects on the Albanian financial system, but indirect effects were visible based on the general slowdown of the foreign markets and public loss of confidence towards the banking system. Also, the foreign remittances decrease and the liquidity shortage of the public played an important role on the capacity to meet the payment obligations (especially on loans). During 2009, the Albanian Central Bank issued a new regulation on liquidity risk evaluation, monitoring and management. The main objective of the regulation was the determination of the minimal evaluation standards of liquidity risk and its effective management by all banks operating on the Albanian territory. The liquidity risk evaluation and monitoring, as suggested also by the literature, does not depend only on internal financial indexes of banks, but it finds its basis also on broader indexes such as macroeconomic indexes. This analysis is effectuated on the impact and importance these factors have on liquidity risk, considering the banking system composed by 13 banks over a period of five years.
\end{abstract}

Keywords: Albanian banking system, liquidity, liquidity risk, macroeconomic factors.

\section{Introduction}

\section{Objectives and Methodology}

The main objective of this work is to identify the impact of macroeconomic factors on the liquidity risk and evaluate the liquidity robustness of the Albanian banking system, based on the factors trend and banking response.

The analysis is conducted based on 13 Albanian banks over a period of five years, from 2010 to 2014 . The selected period is due to the fact that several banks are new in the Albanian financial environment, so their financial statements are not available, which makes impossible their liquidity position calculation. The used program is Eviews 7.0, given the panel data analysis. One time lag was used for the independent variables to eliminate the non stationary data. A regression analysis based on the Fixed Effect regression method is used. The considered dependent variable is the index liquid assets/short term liabilities. The independent macroeconomic variables are: the inflation rate, the unemployment rate, GDP growth, public deficit, interbank interest rate, and interest rate on loans, regulatory capital adequacy and the non performing loans rate. The data is collected by the Albanian Central bank publications regarding to the macroeconomic indexes and calculated by the author regarding to the bank's liquidity index (based on the annual financial statements).

Hypothesis:

$H_{0}: \beta 1=\beta 2=\beta 3=\beta 4=\beta 5=\beta 6=\beta 7=\beta 8=0$, (None of the macroeconomic variables affects liquidity).

$H_{a}: \beta 1=\beta 2=\beta 3=\beta 4=\beta 5=\beta 6=\beta 7=\beta 8 \neq 0$ (At least one macroeconomic variable affects liquidity).

\section{Literature Review}

Although liquidity and its components have a crucial importance in the well functioning of the financial markets, visible as well during the financial crisis, its measurement still remains difficult and not complete. The liquidity risk determinants we have mentioned until now are mainly related to close financial aggregates and indexes, arising from financial institutions statements. The financial crisis originates from single financial institutions and was propagated in the whole economic system, becoming a systemic crisis. Thus, it becomes natural to assume that the financial components are not the only liquidity determinants, but also macroeconomic determinants may influence the liquidity quantity and quality in the market. 
Different authors have studied through econometric models the relationship between liquidity and macroeconomic aggregates.

In her analysis related to liquidity risk determinants in the commercial banks in Czech Republic, Vodova (2011) concludes that macroeconomic aggregates have a notable impact on banks liquidity. Especially, the inflation rate assumes a deteriorating position not only on the overall economy, but also on the banks liquidity, thus there is a negative relation between high inflation rate and available liquidity for banks. The high lending interest rates also have a positive impact in banks liquidity, as it discourages banks to lend more. Also, the non performing loans increase creates a negative relation with liquidity, as high grade of nonperforming loans induces banks to ration or crunch credit, thus preserving liquidity. Through prudential liquidity management banks avoid credit risk. Positive coefficient of GDP growth rate signals an inverse relation between liquidity and business cycles. This conclusion is explained by the fact that many borrowers tend to ask more loans to finance their projects during expansion. On the other side, banks wand to satisfy the increasing loans demand, thus facing less liquidity. Regarding the interbank interest rate, it is positively related to liquidity, as banks are induced to invest in interbank market, which balances are part of liquid assets for the banks. Related to the banks size, a controversial conclusion was reached, affirming the principle "too big to fail". In fact, smaller banks result more liquid, as the big banks relying on the mentality of "too big to fail" or at least to the possibility to rely on the Lender of Last Resort, are not oriented to maintain sufficient liquid assets. Vodova concludes that unemployment, interest margin, bank profitability and monetary policy interest rate have no statistically significant effect on the liquidity of Czech commercial banks.

According to Vodova (2011) the study on macroeconomic factors impact on liquidity in Slovakia there is a negative relation between bank liquidity and financial crisis. Bank liquid assets, or more precisely the share of liquid assets in total assets and in deposits and short term funding, decreases also with higher bank profitability, higher capital adequacy and bigger size of bank. Liquidity measured by the share of loans in total assets and in deposits and short term borrowing increases with the growth of gross domestic product: borrowers reduce their debt during expansionary phases and increase the demand for loans in recessions. This fact is also the reason why banks tend to lend more (and thus decrease their liquidity) even in periods of higher unemployment and lower profitability. There is no significant relation between interest rates, the share of non-performing loans and the rate of inflation with liquidity quantity in the Slovak Commercial Banks.

Trenca et al. (2015) in their study on macroeconomic factors impact on liquidity in Greece, Portugal, Spain, Italy, Croatia and Cyprus arrive at the same conclusions as Vodova, with some particularities related to the last period liquidity, public deficit and unemployment. An increase in public deficit will involve increasing bank loans and thus will decrease liquidity. Also a positive impact of the previous period liquidity was found. The lowest impact on the evolution of liquidity has the $\mathrm{GDP}$, and the greatest impact has the inflation rate.

\section{The Albanian Macroeconomic Environment}

Based on the findings of these authors we may effectuate an empirical analysis related to the Albanian economic environment and the related factors which may influent liquidity.

On the table below are shown the most important macroeconomic indicators during 2010-2014. All the values are expressed in percentage.

Table 1. Macroeconomic Data 2010-2014

\begin{tabular}{|c|c|c|c|c|c|}
\hline & 2010 & 2011 & 2012 & 2013 & 2014 \\
\hline Inflation rate & 3,4 & 3,5 & 2 & 1,9 & 1,6 \\
\hline GDP Growth Rate & 3,75 & 3,17 & 1 & 1,45 & 1,45 \\
\hline Unemployment & 13,5 & 13,32 & 13,32 & 15,7 & 12,9 \\
\hline Public Deficit $^{1}$ & 3,1 & 3,5 & 3,4 & 4,8 & 5,1 \\
\hline Capital Adequacy (Tier1/Total Assets) & 15,4 & 15,6 & 16,2 & 17,96 & 16,84 \\
\hline Interest rate on loans & 12,59 & 11,92 & 10,59 & 12,74 & 8,6 \\
\hline Interbank interest rate (daily) & 4,93 & 5,08 & 3,93 & 3,5 & 2,56 \\
\hline Interbank interest rate (weekly) & 5,14 & 5,23 & 4,17 & 3,62 & 2,65 \\
\hline Non Performing Loans Lek and Foreign Currency & 13,90 & 18,25 & 22,5 & 23,5 & 22,8 \\
\hline
\end{tabular}


The public deficit is expressed as the ration of public deficit in terms of GDP. Source: Albanian Central Bank, Author's estimation

\section{The Inflation Rate}

The principal objective of the Albanian Central Bank concerns the inflation rate targeting. The maximum fixed threshold of the prices variation is $3 \%$. During the recent years a significant decrease was experienced in the inflation rate. According to the studies, this decrease should affect positively liquidity in the banking system.

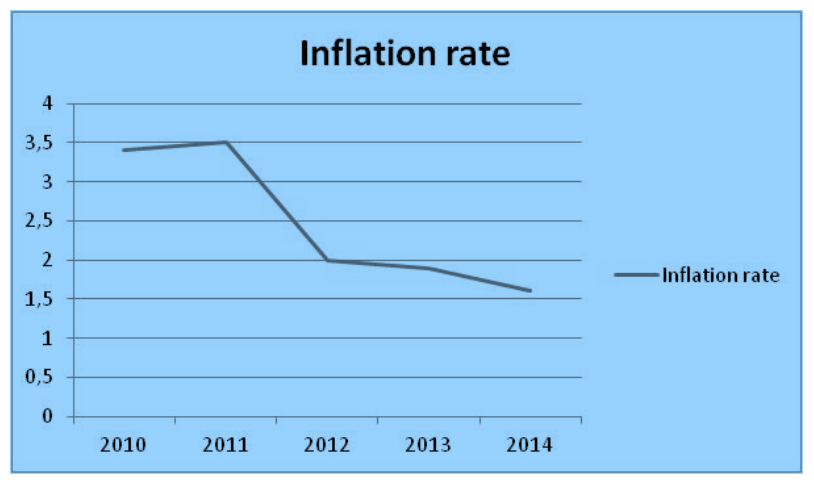

Fig. 1. The Inflation Rate 2010-2014 Source: Albanian Central Bank, The Author's estimate

\section{GDP Growth Rate}

The measure of this indicator is often controversial in Albania. However, it is notable that the GDP growth rate during these years has dropped and the investors try not borrowing during depression periods. Banks try to be more prudent and to preserve their liquidity. This may be explained later, even with the continuous intervention of the Central Bank lowering the basis interest rates in order to incentive the lending and borrowing process.

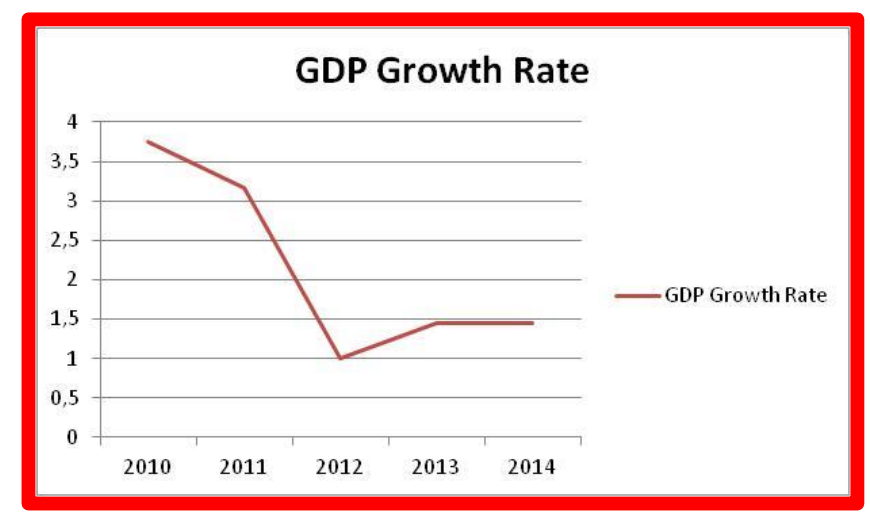

Fig. 2. GDP Growth Rate 2010-2014, Source: Albanian Central Bank, The Author's estimate

\section{The Public Deficit}

The significant public deficit increase during these years has played a negative role in the Albanian economy, especially under the fiscal policy implementation point of view. Most part of the public deficit is financed through foreign capitals lending and Government Treasury bills ( $3,6,9,12,18,24$ months of maturity), issued and managed by the Central Bank. The yield rate applied to these instruments has been subjected to great decreases in order to decrease the deficit burden. Hence, banks liquidity is oriented towards this investment, which is considered secure and easily convertible in cash. 


\section{Capital Adequacy Rate}

The capital adequacy rate has increased until 2013, and decreased during 2014. This decrease is due to the increased incidence of some downgrading assets in banks portfolios, classified as risky. However, the Central Bank threshold regarding the regulatory minimum capital is $12 \%$, thus the banking sector is still considered well capitalized. The effects of capital adequacy decrease are negative on the banking liquidity, as an indicator of bad quality assets and incapacity to be easily converted in cash. Also, it increases the banks opportunity cost and decreases profitability.

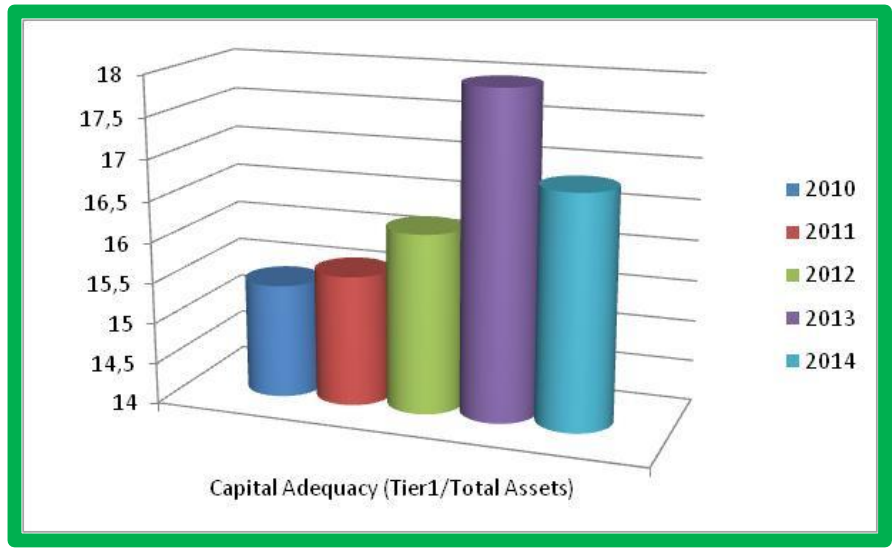

Fig. 4. The Capital Adequacy Ratio, Source: Albanian Central Bank, The Author's estimate

\section{Interbank Interest Rate and Interest Rate on Loans}

These indicators have been progressively decreased year by year based on the Central Bank intervention and policy. The aim objective was to increase the banks incentives to lend towards other similar institutions and to decrease the debt cost for households and businesses.

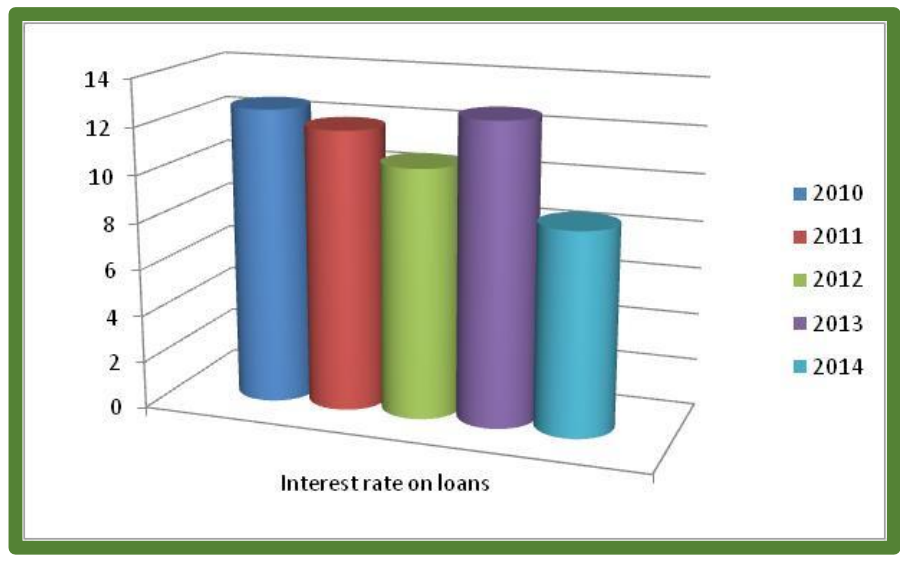

Fig. 5. The Interest Rate on Loans, Source: Central Bank, Author's estimate

The Central bank policy is oriented towards the loans demand accommodation and to the economic growth acceleration. Lower interest rates indicate less liquidity in the markets, as banks are more oriented to lend, in order to increase profitability, based on the number of borrowers. 


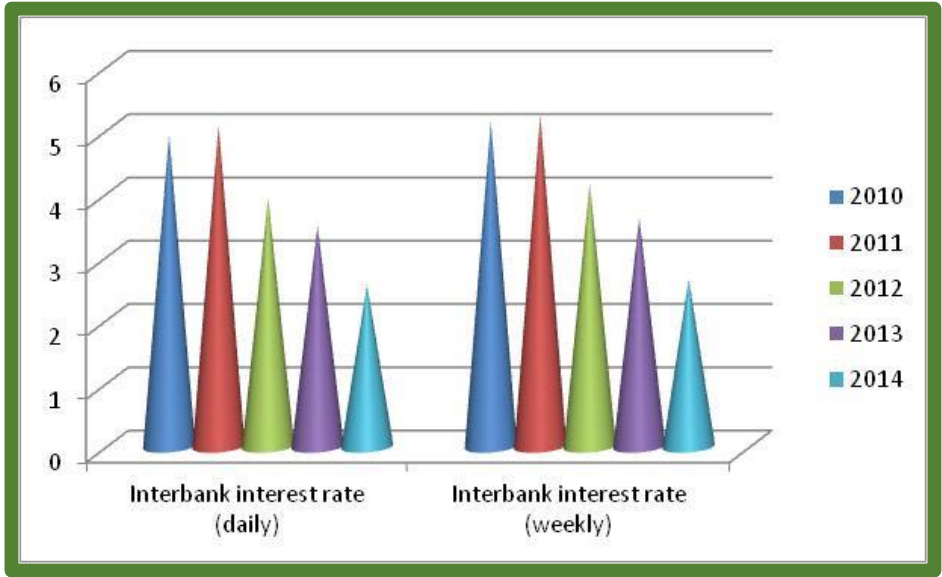

Fig. 6. The Interbank Interest Rate 2010-2014, Source: Albanian Central Bank, Author's estimate

\section{The Non Performing Loans}

During 2010-2013 a positive progress in nonperforming loans is notable. This increase may be caused by the impact of other macroeconomic factors such as the slow growth rate, the currency depreciation and the increased unemployment rate. The slowdown of the economic activity, through which the borrower provides his incomes, has a negative impact on the borrower's capacity to pay back the loans. Also, during these years notable amounts of loans have migrated from a high category to bad loans category. A slight improvement on non performing loan rate of $0.7 \%$ was registered during 2014. The deterioration of the loans portfolio in the banking system leaded to capital adequacy and liquidity decrease also.

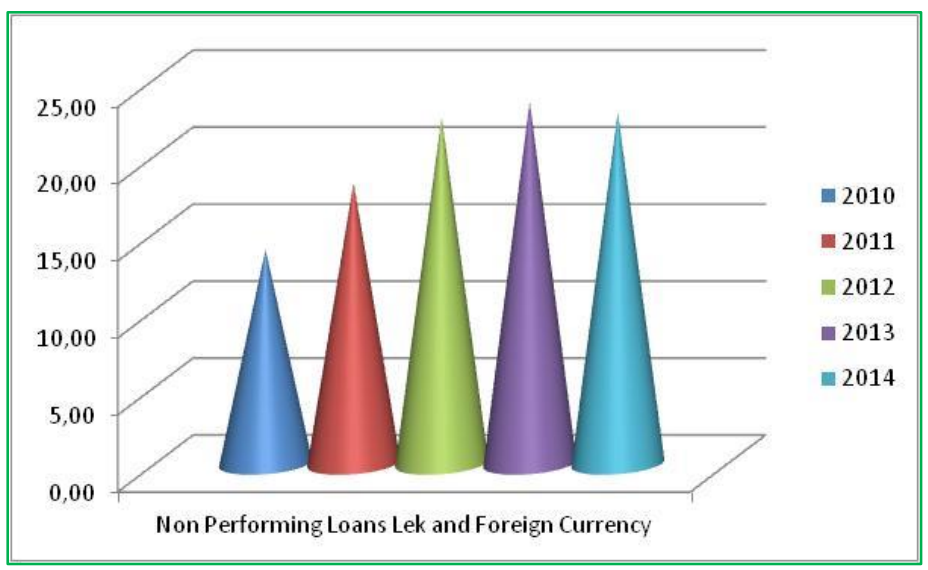

Fig. 7. The Non Performing Loans Rate 2010-2014, Source: Albanian Central Bank, Author's estimation

\section{The Liquidity Measurements in Practice}

Different authors (Aspaachs et al. 2005, Moore 2010, Bessis 2009, Praet and Herzberg 2008) give different measurement methods of liquidity. We can affirm that these indexes are all suitable to liquidity measurement, as based on the financial statements components and express different sensitivity to each of them. In order to better represent the liquidity position of the Albanian commercial banks the considered indexes will be four:

The first liquidity indicator we will consider is the liquidity index as follows:

$L I Q R=$ liquid assets/total assets 
This indicator gives an overall liquidity situation of the banks and the related capacity to absorb liquidity shocks. Higher the liquid assets in the bank's portfolio, higher the capacity to face the liquidity lacks.

The second indicator is represented by the liquidity mismatch:

\section{LMM = Liquid Assets/ Deposits+short term Borrowing}

This indicator is more sensitive to the bank's ordinary activity. In fact, it's capacity to face liquidity lacks depends on the way it selects its funding through household deposits, enterprises or other financial institutions). This ratio has to assume a value higher than $100 \%$, thus the liquid assets should be high enoght in order to cover the funding vulnerability. A robust Liquidity Mismatch ratio makes the bank able to meet its payment obligations.

The third indicator is the loans to deposits index:

\section{$L A=$ Loans/Total Assets}

This index is an expression of the amount assets the bank has tied up in illiquid activities such as loans. Higher the value of the ratio, higher the illiquidity of the bank will be.

The last index is represented by the Loans to assets index:

\section{$L D=$ loans/Deposits+short term financing}

This indicator is similar to the third. Higher values of Loans to Deposit ratio, represent a high grade of illiquidity for the bank.

\section{The Econometric Analysis and findings}

The regression model we are going to estimate is:

$Y=\alpha+\beta 1 X 1+\beta 2 X 2+\beta 3 X 3+\beta 4 X 4+\beta 5 X 5+\beta 6 X 6+\beta 7 X 7+\beta 8 X 8+\mu i$

Where:

$\mathrm{Y}=$ dependent variable represented by the index Liquid Assets/Short term Liablities

$a=$ the intercept of the line

$\beta i=$ the coefficients marking the slope of the independent variables

$X i=$ the independent (explanatory) variables

$H 0: \beta 1=\beta 2=\beta 3=\beta 4=\beta 5=\beta 6=\beta 7=\beta 8=0$, (None of the macroeconomic variables affects liquidity).

$\mathrm{Ha}: \beta 1=\beta 2=\beta 3=\beta 4=\beta 5=\beta 6=\beta 7=\beta 8 \neq 0$ (At least one macroeconomic variable affects liquidity).

The hypothesis testing will be based on the $\mathrm{F}$ statistic, $\mathrm{t}$ level significance and the $\mathrm{P}$ probability value. The $\mathrm{H} 0$ will be rejected probability $P$ is less than $\alpha=0,05$ or if $F$ results in higher than the critical value according to the degrees of freedom.

After transforming the data in one time lag to eliminate correlation and in natural logarithm to eliminate heteroschedasticity the output obtained for the index Loans to Assets (LA) is:

\begin{tabular}{|l|l|l|l|l|}
\hline Variable & Coefficient & St. error & Prob & R squared \\
\hline C & 3.744047 & 0.291709 & 0.0000 & 0.94 \\
\hline NPL & 0.005462 & 0.008824 & 0.5088 & \\
\hline UNT & -0.028090 & 0.014814 & 0.0640 & \\
\hline INFR & -0.018505 & 0.070683 & 0.7946 & \\
\hline INTBR & 0.088631 & 0.044996 & 0.0547 & \\
\hline
\end{tabular}

The output results show a high explanatory power and a significant relation between the loans to assets liquidity measure and the interbank rate and unemployment. Thus, regarding to the unemployment rate the relation is negative as expected. 
A high unemployment rate causes a decrease in the LA index, due to the fact that banks do not of will to tie up in riskier activities such as according a loan to people which are not able to meet their obligations in a short/medium period. The relation between interbank rate and loans to assets index is positive. This result is expected as concerning the normal activity of the bank. In fact, lower interbank interest rates affect the lending interest rate on the same side, which increases the public interest on loans making it cheaper and on the other side increasing the banking activity.

The second index, Maturity Mismatch presents the output result as below:

\begin{tabular}{|l|l|l|l|l|}
\hline Variable & Coefficient & St. error & Prob & R squared \\
\hline C & 1.859541 & 0.445226 & 0.0001 & 0.934 \\
\hline CAPAD & 0.094929 & 0.033995 & 0.0074 & \\
\hline IRD & -0.022123 & 0.021301 & 0.3040 & \\
\hline
\end{tabular}

The maturity mismatch index depends strongly on the capital adequacy ratio and its relation is positive. This result is expected as robust capital banks have a higher possibility to meet their obligations even during liquidity shortage.

The third index related to Loans to Deposit Ratio and independent variables gives the result as below:

\begin{tabular}{|l|l|l|l|l|}
\hline Variable & Coefficient & St. error & Prob & R squared \\
\hline C & 5.644921 & 0.490001 & 0.0000 & 0.861 \\
\hline UNT & 0.078303 & 0.030828 & 0.0144 & \\
\hline GDPR & 0.043825 & 0.049190 & 0.3774 & \\
\hline CAPAD & -0.210262 & 0.053865 & 0.0003 & \\
\hline NPL & 0.035513 & 0.018419 & 0.0598 & \\
\hline
\end{tabular}

The explanatory power of the model related to the Loans to Deposit Ratio is quite high. There is a significant relation through this index and the level of unemployment (+), capital adequacy $(-)$ and non performing loans $(+)$. As mentioned above, high levels of this liquidity index show illiquidity for the bank and vice versa. Thus, the interpretation of the relation with the explanatory variables should also be reversed. The positive relation with the unemployment level is expected and explained by the loans demand increase during difficult periods of the work market. The loans level increases and the deposits decrease because of public funds shortage. Thus, the influence on the banks liquidity will be negative. On the other side, the negative sign of the capital adequacy relation to the LDR is expected. The increase in capital adequacy increases the robustness and the bank ability to meet its obligations, affecting the liquidity ratio positively. Also, there is a less significant relation of the non performing loans and $\operatorname{LDR}(+)$. Higher the non performing loans index, lower the banks will to lend further because of increased credit risk. The credit risk increase propagates its effects on liquidity risk increase.

The fourth index (Liquidity Ratio) relation with its explanatory variables is given as below:

\begin{tabular}{|l|l|l|l|l|}
\hline Variable & Coefficient & St. error & Prob & R squared \\
\hline C & 1.035221 & 0.838497 & 0.2229 & 0.805 \\
\hline CAPAD & 0.204992 & 0.077802 & 0.0112 & \\
\hline IRD & -0.056763 & 0.030695 & 0.0705 & \\
\hline NPL & -0.016560 & 0.013072 & 0.2112 & \\
\hline
\end{tabular}

The explanatory power of the model is high also in this case. There is a significant relation through capital adequacy and liquidity ratio $(+)$ and less significant regarding the interest rate differential between loans and deposits (-). The positive relation to capital adequacy is expected as the liquidity ratio represents the capacity of the bank to absorb liquidity shocks which complain the principal role of capital adequacy. On the other side the a positive interest rate differential affects 
negatively the banks liquidity as high interest rates on loans discourage the public to borrow funds, lowering the lending activity and profitability for the bank.

\section{Conclusions}

The results of the analysis basically meet the literature results, considering also the little financial Albanian environment. As a conclusion no relation was found between Pubblic deficit and liquidity indexes in commercial banks. The relation between liquidity indexes and GDP growth rate and inflation rate is not significant. Significant relation was found through liquidity indexes and interbank rate, unemployment rate, capital adequacy, Interest rate differential, and non performing loans.

\section{Bibliography}

[1] Albanian Central Bank, Annual Report 2010-2014.

[2] Aspachs, O. - NIER, E. - TIESET, M. (2005). Liquidity, Banking Regulation and the Macroeconomy. Evidence on bank liquidity holdings from a panel of UK-residents banks. Available at: http://www. bis. org/bcbs/events/rff05AspachsNierTiesset. pdf.

[3] Bessis, J. (2009). Risk Management in Banking. Chichester: John Wiley \& Sons.

[4] Moore, W. (2010). How do financial crises affect commercial bank liquidity? Evidence from Latin America and the Caribbean. MPRA Paper 2010-21473. Munich: Munich Personal RePEc Archive.

[5] Trenca et al. (2015). Impact of Macroeconomic Variables upon the Banking System Liquidity. Available at: http://www. sciencedirect. com/science/article/pii/S221256711501583X

[6] Vodova P. (2011) Determinants of Commercial Bank's Liquidity in Slovakia Available at: http://www. naun. org/main/NAUN/ijmmas/20-855. pdf 